\title{
Pesticides: An Overview of the Current Health Problems of Their Use
}

\author{
Raffaella Leoci ${ }^{1}$, Marcello Ruberti ${ }^{2 *}$ \\ ${ }^{1}$ Department of Emergency and Organ Transplant (D.E.T.O.), Section of Veterinary and Animal Production, University of Bari \\ "Aldo Moro", Bari, Italy \\ ${ }^{2}$ Department of Economic Sciences, University of Salento, Lecce, Italy \\ Email: leocivet@yahoo.it, *marcello.ruberti@unisalento.it
}

How to cite this paper: Leoci, R., \& Ruberti, M. (2021). Pesticides: An Overview of the Current Health Problems of Their Use. Journal of Geoscience and Environment Protection, 9, 1-20.

https://doi.org/10.4236/gep.2021.98001

Received: June 18, 2021

Accepted: August 2, 2021

Published: August 5, 2021

Copyright $\odot 2021$ by author(s) and Scientific Research Publishing Inc. This work is licensed under the Creative Commons Attribution International License (CC BY 4.0).

http://creativecommons.org/licenses/by/4.0/

\begin{abstract}
The necessity to produce increasing quantities of food to meet the demand of ever-increasing populations has led to the massive use of pesticides in agriculture. Their massive consumption derives from the need to subtract food from competition of fungi, bacteria, and insects and agricultural land from the invasion of competing weeds. Modern agriculture floats on an ocean of synthetic chemical compounds used to crop protection and food preservation during storage. Presently, worldwide about 2000 active ingredients have been listed, categorized into about 60 classes of chemicals. In the world, the overall pesticides, used in agriculture, are about 4.1 million tonnes/years. The exposure of animals and humans to pesticides could be related to neurotoxicity, endocrine disruption, liver and kidney damage, cancer, reproductive effects (sperm abnormalities, decreased fertility, fetal growth retardation, birth defects, or spontaneous abortion), and growth modifications. However, the knowledge about their potential damage to the organs of reproduction, breastfeeding, and infants is still largely insufficient. It is necessary to improve new methods to identify and regulate the long-term safety of pesticides use, to protect the environment and health, and to eliminate the adverse effect of pesticides on the environment and non-target organisms. The assessment of possible risks of old and new pesticides must be increased to include the possible effects on reproduction on animals and pregnancy loss even after a long time. In the meantime, it is necessary to minimize the use of synthetic chemical compounds by increasing the use of biological systems.
\end{abstract}

\section{Keywords}

Pesticides, Environment, Animals, Humans, Health 


\section{Introduction}

The massive use of pesticides is considered one of the main factors affecting the environment (Mahmood et al., 2016). Dichloro-diphenyldichloroethane (DDT) had been widely used since the 40 s of the last century for the control of mosquito infestations, initiated the rapid spread of the use of pesticides throughout the world. Currently, large quantities of them-about 60 chemical classes that group over 2000 active ingredients are used to protect agricultural crops from a long series of pests (insects, fungal and bacterial attacks, weeds, rodents, etc.) (Vidal \& Frenich, 2006; Bolognesi \& Merlo, 2011; FAO, 2021).

Worldwide, every year many hundreds of new pesticides are formulated. Because some of them are very uneconomic to produce, they never reach the production line or sales counter. However, even those, which get through the limits imposed by local or state agencies, cannot automatically be considered safe.

Almost all of them, in addition to the declared active ingredient, contain adjuvant substances, whose chemical composition is often not well defined and kept confidential by the manufacturing companies, making them included under the generic category of inert substances (Mesnage et al., 2014). These additives and inert compounds, which make up most of the current commercial formulation (90\% - 95\%), in some cases show even more toxic properties than the active ingredient itself (Meftaul et al., 2020). Pesticides, once released into the environment, often decompose into degradation products that may pollute foods, soils, surface waters, and groundwaters (Tiryaki \& Temur, 2010).

The EU "Plant Protection Regulation" (PPR) (Regulation 1107/2009/EC) recognises that pesticides have significant responsibility for environmental degradation.

During 2017-2018, more than one hundred pesticides, some of which are still considered very dangerous and prohibited in several countries, have been approved by US-EPA. A large part (approximately, one third) of these commercial formulations contained a mix of active ingredients (neurotoxic organifisfates and carbamates, paraquat, chloropicrin, fumigants, methyl bromide, etc.), some of which, defined by EPA itself, as "probable" or "known" carcinogen (Donley, 2020).

The European Union Regulation concerns about 1100 pesticides, presently or previously used in agriculture, and establishes Maximum Residue Levels (MRL) for 315 agricultural products. 224 different chemical principles have been detected in Italy by the "Istituto Superiore per la Protezione e la Ricerca Ambientale" (ISPRA, 2018) into 60\% of surface waters (AMPA, glyphosate, metachlor-esa, imidachloprid, metolachlor, etc.) and $30 \%$ of ground deep waters (atrazine des. desis, flonicamid, metolachlor, terbuthylazine, etc.). Also, researchers from the "Mario Negri" Institute of Pharmacological Research in Milan had previously found, in many water wells in Northern Italy, conspicuous concentrations in drinking water of propazine (up to $30 \mathrm{ppt}$ ) and simazine (up to $200 \mathrm{ppt}$ ).

(Silva et al., 2019) evaluated the residue presence of 76 pesticides in 317 agri- 
cultural European soil samples. They observed that about $25 \%$ of the soil samples examined contained one residue and $58 \%$ of the samples contained more than one residue. As evidenced by other research (Stehle \& Schulz, 2015), among the substances that most frequently exceed the limits allowed by law, there are glyphosate and neonicotinoids.

This overall situation can be complicated by simultaneous use of different products and complex mixtures with unpredicted cocktails' effects on the environment and life (Maksymiv, 2015; Milo, 2020; Geissen et al., 2021). Regarding the chemical interaction of pesticides, between them and with organic substrate, much obviously depends on the nature of compounds, that is, on their chemical family, on their doses, on climate (Hernández et al., 2017; Koli et al., 2019) and sensitivity of the organs and tissues subject to intoxication (Ghuman et al., 2013). The impacts of pesticides and environmental stress or so (habitat destruction, invasive alien species, and so on) on animals are equally little known (Ito et al., 2020).

\section{Classification and Use in Agriculture}

There are many ways to group pesticides. They can be grouped, i.e., according to their chemicals or to the method of application or, more commonly, to the pests species: Insecticides, Herbicides, Rodenticides, Bactericides, Fungicides and Larvicides. According (Eurostat, 2008), "pesticide" is a non-specific word concealing:

1) Products for plant protection (Council Directive 91/414/EEC);

2) Biocides (Directive 98/8/EC).

In the FAOSTAT Pesticides Use domain (FAO, 2021), there is information about the following main pesticides groups (Table 1).

At the beginning of the 90s, a new revolution occurred in this field: Neocotinoids (such as acetamiprid, imidacloprid, thiamethoxam, nitrosoguanidine, etc.) were introduced (Frederickson et al., 2016). The main difference between these new substances and those used previously (chlorine compounds, such as DDT, and organo-phosphate insecticides) consists in their lower dose of use: a few grams of chemical compound per hectare in comparison to several kilograms per hectare (Reynoso et al., 2019).

USA, EU, Brazil, and China are the world's major farming producers and consumers of pesticides.

According to FAO (2021), 4.1 million tonnes of pesticides have been used in agriculture globally in 2018, which was 35\% greater than in 2000 (Maggi, Tang, La Cecilia \& McBratney, 2019).

In the 2018 top ten world users of agricultural pesticides, the first three countries (representing $80 \%$ of the consumption of the countries included in this ranking) are China (1774 kt), USA (408 kt) and Brazil (377 kt). The main contributor continent is Asia: About 50\% of the world total pesticides use in 2018 . Herbicides have a relative overall consumption share of $38 \%$, fungicides $32 \%$, 
Table 1. Pesticides groups.

\begin{tabular}{ll}
\hline 1) Insetticides & $\begin{array}{l}\text { Organo-phosphates, Chlorinated hydrocarbons, Pyrethroids, } \\
\text { Carbamates-insecticides, Biological products and Others }\end{array}$ \\
2) Mineral Oils & \\
3) Herbicides & $\begin{array}{l}\text { Triazines, Phenoxy hormones, Carbamates-herbicides, } \\
\text { Amides, Urea derivatives, Sulfonyl urea, Uracil, Dinitroanilines, } \\
\text { Bipiridils and Others }\end{array}$ \\
4) Fungicides and Bactericides & $\begin{array}{l}\text { Inorganic, Benzimidazoles, Dithiocarbamates, Diazines } \\
\text { Morpholines, Triazoles Diazoles, and Others }\end{array}$ \\
5) Seed Treatment-Fungicides & $\begin{array}{l}\text { Benzimidazoles, Dithiocarbamates, Diazines Morpholines, } \\
\text { Botanical products and biological, Triazoles Diazoles, and Others }\end{array}$ \\
6) Seed Treatment-Insecticides & $\begin{array}{l}\text { Carbamates-insecticides, Organo-phosphates, Pyrethroids, } \\
\text { and Others }\end{array}$ \\
7) Plant Growth Regulators & \\
8) Rodenticides & $\begin{array}{l}\text { C Cyanide Generators, Anti-coagulants, Narcotics, } \\
\text { Hypercalcaemics, and Others yanide Generators, } \\
\text { Anti-coagulantsNarcotics, Hypercalcaemics, and Others }\end{array}$ \\
9) Other Pesticides NES & \\
10) Disinfectants & \\
\hline
\end{tabular}

and insecticides $29 \%$. In particular, herbicides contribute approximately $50 \%$ of the pesticides applied in agriculture (FAO, 2021).

The most used pesticides are herbicides and insecticides (FAO, 2021). Among herbicides, the most common ones are glyphosate and isoproturon, the effects of which we discussed in previous notes (Leoci \& Ruberti, 2020a; Leoci \& Ruberti, 2020b). Among insecticides, chloropicrin (trichloronitromethane) is widely used as fumigant, despite numerous limitations (Ayres, 1919; Leoci \& Ruberti, 2020b).

According to (FAO, 2021), the average annual use of pesticides per area of cropland has grown continuously from 1990 to 2018 for all the countries of the different continents, marking the highest quotas for the Asian ones (from about $2.2 \mathrm{~kg} / \mathrm{ha}$ in 1990 to about $3.6 \mathrm{~kg} / \mathrm{ha}$ during 2018, with a maximum of $3.8 \mathrm{~kg} / \mathrm{ha}$ during the years 2011-2012). The lowest use rates are those of African countries that about $0.4 \mathrm{~kg} / \mathrm{ha} /$ year from 1990 to 2018 . Consumption has been fairly constant in European countries as a whole, with values of about $1.4-1.8 \mathrm{~kg} / \mathrm{ha} /$ year from 1990 to 2018.

\section{Economic Aspects}

\subsection{Global Market}

According to (FAO, 2021), at the global level, total pesticides trade reached approximately 5.9 million tonnes in 2018 , with a value of $\$ 37.6$ billion. The global trade of hazardous pesticides, monitored under the Rotterdam Convention, decreased substantially during the period 2007-2018. Since 2016, Asia became an equally important exporter, reflecting the high economic growth of this region. Pesticides exports increased by 2.5 fold in the Asia region in the period 2011-2018 
compared to 2001-2010. This trend was driven mainly by China, which was responsible for almost two-thirds of pesticides exports from Asia in 2018. Asia, nonetheless, remained below Europe in terms of total export value, reflecting the high-quality pesticides produced under the EU Common Agricultural Policy.

In 2018 around $\$ 15$ billion was spent on pesticides in USA, representing a five-fold increase since 1960 when adjusting for inflation (Gro, 2021). According to (MacArthur \& Murray, 1993), USA constituted approximately one-third of world pesticides production, $75 \%$ of which was sold domestically and $25 \%$ exported.

According to (FAO, 2021), the top five countries for total pesticides imports in 2018 were Brazil, France, Germany, Canada, and USA, with trade values ranging $\$ 1.4$ - 3.0 billion. In these countries, imported quantities roughly doubled during the period 1990-2018. The top five exporting countries in 2018 were China, Germany, USA, France and India, with values ranging \$3.0 - 5.5 billion. With regards to the thirty-five hazardous pesticides covered under the Rotterdam Convention, the top five importing countries in 2018 were Myanmar, Malaysia, the Philippines, Thailand and Costa Rica, with values ranging \$20 - 80 million. Imports decreased during 2007-2018 in all these countries, with the exception of Myanmar, which is not a signatory to the Convention. The top five countries exporting hazardous pesticides in 2018 were USA, Thailand, South Africa, Nige-ria and Malaysia, with values ranging \$10-30 million (FAO, 2021).

As for the EU (27 EU Member States), according to (Eurostat, 2020), during 2011-2018, the consumption of pesticides persisted to be substantially stable at around 360,000 t/y, remaining concentrated (over two thirds) in only four countries (Germany, France, Italy and Spain). The best-selling chemical formulations were fungicides (45\%), herbicides (32\%) and insecticides (11\%).

\subsection{Environmental Costs}

Even if the economic costs of biodiversity loss are very uncertain, variable and dependent by historical context, in the United States of America, some studies have estimated that the economic impact on ecosystems, in terms of loss of insects pollinators, aquatic life and birds could amount to hundreds of billions of dollars per year (Chapin et al., 2020).

According to other estimations, biodiversity and ecosystems have an economic assessment of 10 - 100 times greater than the costs of the conservation of natural habitats (Gómez-Baggethun \& Martín-López, 2010). The added value to economic production brought by pollinating insects, for example, is considerable contributing to about $5 \%-8 \%$ of world agricultural production, equal to 235 - 577 billion dollars in 2015 (OECD, 2019).

In addition to these consequences, there are supplementary economic effects correlated to the recreational use of ecosystems and wildlife: hiking, hunting, fishing, birdwatching, etc. All these activities strongly depend on the presence of insects in ecosystems; insects represent a very important food base of natural ecosystems. Unfortunately, the massive and often indiscriminate use of insecti- 
cides has drastically risen numerous populations of insects all over the world.

However, the problem is even more serious: in fact, the IUCN Red List, while it has estimated that only about 8000 species of insects are at risk of extinction, has hypothesized, in the medium-long term and in countries with input-intensive agricultural systems, the total disappearance of many mammals and bird species. It has been estimated, for example, thanks to the research of amateur entomologists, that insect populations in Germany have fallen by $75 \%$ in just 25 years (Hallmann et al., 2017; Hance, 2019).

\section{Adverse Effects on Environment}

As is well known, pesticides are not only an excellent weapon for the defense of crops and to guarantee high levels of harvest, but in many cases they are also the only available tool when it is necessary to intervene in emergency situations to eradicate parasitic attacks. However, as is also well known, pesticides seriously undermine the health and well-being of natural habitats and biodiversity, also because they easily migrate to other environmental compartments due to runoff and leaching phenomena (Ewald et al., 2015; Hallmann et al., 2017).

In the meantime, wind and evaporation can transfer pesticides into the atmosphere, causing contamination of other ecosystems and sites also very far from the place where they were used (Dubus et al., 2000; Ritter, et al., 2002). An example is given by chlorothalonil (2,4,5,6-tetrachloroisophthalonitrile), also found in traces in the Evian's waters, considered pure as they come from the heart of the French Alps (De Neri, 2020).

The excessive use of pestides and their consequent relative cocktails has also had heavy repercussions on the qualitative characteristics of soils for agricultural use (Geiger et al., 2010) impairing the ability of the soil to host a wide variety of crops (Dinis-Oliveira et al., 2006) and to perform other ecosystem services with long-term implications even in soils of organic farms, as some scholars (Geissen et al., 2021) have shown.

Other researches (Hussain et al., 2017) showed that pesticides interact with the microflora, microfauna and macrofauna of the soil by modifying the chemistry of the soil and the exchange of soil substances with the roots of the plants and hindering, for example, the processes of biological fixation of atmospheric nitrogen by rhizo-bacteria.

\section{Adverse Effects on Animal Health}

Regarding the specific effects on humans and/or animals, we report the following most recent research (last five years), referring to the bibliography cited for an in-depth study of certain aspects. Just to get an idea of the huge number of scientific articles published in the last five years, using as keywords "pesticides", "effects" and "humans"/"animals", on Pubmed we found, respectively, over 9000 and 13,000 papers, while through the Sciencedirect search engine we found 38,000 and 25,000 papers. It is not easy to disentangle in this scenario, so we 
have sought and selected only those articles that are most significant for us and most cited by recent scientific bibliography.

According to some authors (Beketov et al., 2013; Vogel, 2017), the use of pesticides within the European territory, in the period 1989-2013, led to very substantial reductions in biodiversity: up to $40 \%$ for invertebrates, up to almost $80 \%$ for insects and up to nearly $90 \%$ for pollinating insects such as bees.

Some authors, such as (Lushchak et al., 2018), have considered the adverse health effects on animal organisms of pesticides after ingestion, inhalation or dermal contact. This intoxication can lead to cancer, neurotoxicity, reproductive effects, endocrine disorders, liver and kidney damage, and teratogenicity ("Beyond Pesticides" (World Organization)).

\subsection{On Birds}

After the alarm raised by (Carson, 1962), the worsening of the situation has also been observed by other scholars. A few decades later, in Great Britain, confirming the findings of other studies, a rapid and significant decline in the populations of birds that feed on the seeds of weeds destroyed by herbicides was observed (MacKinnon \& Freedman, 1993). Even in tropical and sub-tropical areas, the indiscriminate use of herbicides has greatly reduced the agricultural areas used by wintering migratory birds (Newton, 2004).

Already (Blus \& Harry, 1997) showed that even when low-toxic herbicides were used in forestry, significant reductions in bird populations occurred probably due to the corresponding reduction in many plant species used as their food sources.

More recently, some researchers (Eng et al., 2019) of the University of Saskatchewan and York University (Canada) have examined the singing behavior of a migratory bird: the "white-crowned sparrow" (Zonotrichia leucophrys). Imidacloprid ingested in the wild by this bird, in realistic amounts of 1.2 or $3.9 \mathrm{mg} / \mathrm{kg}$ b.w., influenced not only the amount of body fat deposits but also the migratory and reproductive capacity of males of this species and their own survival rate. In fact, neocotinoids, through an articulated neurotoxic mechanism of stimulation of the nicotinic acetyl-choline receptor (nAChR), cause an overstimulation of the nervous system, not only of insects, but also of vertebrates such as birds (Tomizawa \& Casida, 2003).

\subsection{On Bees and Bats}

Another research (Eng et al., 2017) has confirmed the suspicions about the adverse effects of neonicotinoids on the behavior and survival of birds and pollinators such as bees, so that the EU banned three of these compounds in 2018. The damage of neonicotinoids on bees, bumblebees and other species of beneficial insects has now been confirmed by many other studies (Long \& Krupke, 2016; Arce et al., 2017; Phelps et al., 2020).

As it was to be supposed, not even bats escape the action of pesticides, having 
an omnivorous diet and thus exposing themselves to a wide range of contaminants as has been ascertained by (Oliveira et al., 2020), even if the populations of these mammals are still the least studied regarding the effects of pesticide residues on their health. The negative effects of pesticides, in fact, also occur on taxons, like bats, which are usually overlooked in toxicity studies, although they are important living species that play a large role in ecosystems as they disperse plant seeds and keep controlling the spread of pests. According to (Berny, 2007) and others (Van Oers et al., 2005), the abuse of pesticides is responsible, depending on the geographic area, for the poisoning of $18 \%$ - $68 \%$ of wild animals.

\section{Adverse Effects on Human Health}

The environmental risks and health effects on humans of several pesticides are not wellknown. In 2006 an alarming paper appeared in the Lancet (Grandjean \& Landrigan, 2006) presenting a list of 202 substances known to be toxic to the human brain, 90 of which were pesticides.

In any case, as has also been highlighted, considered the presence of hundreds of active ingredients available and the continuous placing on the market of new molecules, the detailed knowledge of their toxic action on humans, especially if at minimal doses and prolonged time, is undoubtedly complex and difficult to be exhaustive. At the same time, many scientific studies have highlighted that these molecules can act in a wide range on all the vital functions of human cells by inducing a long series of alterations: genetic and epigenetic modifications, imbalances in receptor function with an action of "endocrine interference", mitochondrial dysfunction, disturbance of neuronal conduction due to alteration of ion channels, alteration of enzymatic activity, especially due to interference with acetylcholinesterase, oxidative stress, stress of the endoplasmic reticulum and impaired aggregation of proteins and others (Bianco, 2018).

Since food is the main route of intake of pesticides for consumers, their residues in food can represent dangers to human health (Bjørling-Poulsen et al., 2008) and the presence of them in feed products can involve risks for the health of farmed animals and risks for the consumers themselves because they can enter into the food chain (NRC, 1993). Unfortunately, currently, the regulatory systems for stating average exposure to pesticides do not take into consideration personal situations and types of consumption that differ from the average, as well as particular lifestyles, age, presence of concomitant diseases, etc. Obviously, children are usually the most exposed, due to their fast growth, their lower weight, the greater consumption of fruit in relation to their weight, etc. (Mridula et al., 2013).

As we will learn more lately, eExposure to pesticides, which mimic the chemical structure of hormones classified as endocrine disruptors, causes a series of deformations and a rising of the associated costs for human health (Trasande et al., 2015).

\section{The Case of Chloropicrin}

An interesting study on chloropicrin (or nitrochloroform or hundreds of trade 
names) was conducted by (Oriel et al., 2009) to examine the use of this substance in the State of California as a fumigant in the decade 1992-2003. According to (Prentiss, 1937), wartime exposure to chloropicrin causes dangerous gastrointestinal effects, such as diarrhea, colic and persistent nausea. As reported by (Sciuto \& Kodavanti, 2015; O’Malley, 2010; Raman, 2014), chloropicrin is a potent lung and skin irritant.

Despite the long experience gained in the USA, in Europe chloropicrin is contemplated as a new active substance, because the data available from the USEPA archive regarding the toxicology and mutagenic potential of chloropicrin were considered insufficient by EFSA to establish toxicological values for safe exposure to this chemical. During the approval process according to Regulation 09/1107/EC, it was highlighted that chloropicrin, regarding acute toxicity, has a categorization 4 for all the ways of exposure: irritating to eyes, skin, and respiratory tract; harmful if swallowed; fatal if inhaled (Anastassiadou et al., 2020).

\section{Adverse Effects on Reproduction}

In general and in principle, with regard to the mechanisms of action of pesticides, the ideal situation would be to have highly selective molecules, i.e. highly efficient, and therefore very toxic, for target organisms (pests) and, at the same time, harmless or at least slightly toxic for non-target organisms, obviously including humans. To achieve this goal, the chemical formulation of the active ingredients of many pesticides currently on the market is designed to damage enzymes present only into target organisms and not present in non-target organisms. However, in the natural environment, also due to complex mechanisms and interactions that occur and which are difficult to predict, the molecules of pesticides and their metabolites affect the vital and reproductive functions even of non-target organisms, also very useful for maintaining the delicate ecosystemic balances (Das, 2013).

In fact, as underlined by (Frazier, 2007), many categories of pesticides (pyrethroids, herbicides, organophosphates, fungicides, carbamates, fumigants and especially organochlorines) are potentially able to have adverse effects on development and reproductive endpoints. Reproduction is the essential function that allows continuity of living organisms. Its perturbation or dysfunction leads to negative consequences for human, animal and plant productivity and survival.

Many factors can be responsible for this perturbation (Gardella \& Hill, 2000). Among these, certain pesticides, present in the food chain at sufficient doses, represent a high risk of harm to human and animal health. In fact, they can increase the occurrence of cases of infertility, spontaneous abortions, teratogenicity and delays in fetal development. In the late 1900s, (Gray \& Ostby 1998) confirmed that a multitude of toxic substances, including pesticides, can profoundly alter the development of the nervous and reproductive systems in several species of laboratory guinea pigs.

Pyrethroids, according to what emerges from various studies, are those that 
cause the most serious pathological effects to mother (ovaries, uterus and hormonal system) (Ahmad et al., 2012) and fetus (abortion and teratogenesis) (Auso et al., 2004; Mnif et al., 2011).

A survey, conducted in the USA on women who had undergone treatments to solve infertility problems, found that consumption of fruit and vegetables, probably affected by pesticides, compared to the average, correspondingly increased the risks of termination of pregnancy or missed pregnancies (Yu-Han et al., 2018). Environmental exposure assessments and epidemiological studies show that one of the major culprits of these infertility and miscarriage problems is oxidative stress in excess of the scavenging capacity of antioxidants present within a human or animal organism (Szalárdy, 2006; Banerjee \& Bhattacharya, 2020).

\subsection{Endocrine Disorders and Infertility}

One of the most feared side effects of pesticides is their ability to act as "Endocrine Disrupting Chemicals" (EDCs) (Rattan et al., 2017; Sifakis et al., 2017). In fact, numerous endocrine disruptors, i.e. chemicals (like pesticides) that interfere with the regulation and stability of the endocrine systems of animals (Kavlock et al., 1996), act negatively, as has been shown by many scientific studies conducted in the United States, on the reproductive systems of reptiles, fish and amphibians.

With regard to these endocrine disruptors, much subsequent research is identifying which specific substances can alter the fertility conditions of animals and humans. According to (Upadhyay, 2019), precisely high levels of pesticides, having adverse effects on the endocrine system, are one of the main causes, albeit indirect, of infertility problems for women because they greatly increase the levels of oxidative damage.

Some years earlier, (Gray, 1996; Steer, 1993), continuing the research about pseudo-hermaphroditism following exposure to active substances on hormonal systems, have presented scientific evidence regarding the role and mechanisms of action of pesticides on the reproductive system through the binding of the Ah receptor, antiandrogenicity and toxicity of germ cells.

In the same decade, other authors (Wolf et al., 1999) provided experimental data of about ten antiandrogenic substances: Ketoconazole, procymidone, congener polychlorinated biphenyl n. 169, linuron, clozolinate, p, p'-DDE, diethylhexyl phthalate, iprodione, dibutyl phthalate (DBP). For example, linuron treatment caused testicular atrophy and malformed epididymis, involving RA binding.

According to (Bretveld et al., 2007), pesticides can lead to a series of hormonal disorders and negatively affect the functioning of the central nervous system and thyroid function, the binding and recognition systems of receptors, the correct way of interaction of cells of Leidig and Sertoli.

However, the results of some above experimental studies have been the subject of controversy and denial (Bates et al., 2005). 


\subsection{Disorders of Sexual Functions}

Particularly, (Lindbohm \& Sallmén, 2017) have highlighted that the generic exposure of workers, due to their specific professional activities, to chemically or biologically active substances, like pesticides, can cause genetic mutations and problems with fertility and sexual function: decrease in sexual potency and libido, lowering of sexual hormone levels, alteration of menstrual flow, ovarian dysfunction, delayed menarche, premature menopause, impaired sperm vitality and drastic reduction in male and female fertility. These effects are already known (Sharara et al., 1998).

(Li et al., 2020) identified the residual concentrations of the metabolites of 11 pesticides (including pyrethroids, organophosphate insecticides and herbicides) by examining the urine of a sample of 619 women of childbearing age in the states of California and Utah, detecting high concentrations of chlorpyrifos and chlorpyrifos-methyl (compounds progenitors of TCPY) and diazinon (the parent compound of IMPY), known to be associated with endometriosis phenomena.

(Hu et al., 2020), examining the metabolites present in the spermatic fluid of 346 men of reproductive age in Shanghai (China), correlated the presence of pyrethroids to the reduced fertility parameters of their semen.

\subsection{Fetal Malformations}

Reproductive anomalies and hermaphroditic deformities have been found in many species of animals living in US rivers: mammals, fish, frogs, reptiles, molluscs, etc. (Mnif et al., 2011).

The pesticide residues, then, taken through food, can cause neurotoxicity and interfere with the normal development of cognitive functions of fetus (BjørlingPoulsen et al., 2008).

(Bretveld et al., 2006) found that several pesticides interfere with the proper functioning of sex hormones, significantly disturbing the timing of pregnancy, menstruation and even causing miscarriages and developmental defects in the fetus.

Other previous studies (Yoshida et al., 1987) have investigated possible fetal malformations related to the inhaled administration of chloropicrin for six hours a day during 6 - 15 days before gestation and found no noteworthy adverse effects for doses below the NOAEL. In another multigenerational study (Anastassiadou et al., 2020) administered by inhalation in rats, no adverse effects on reproductive function and fetal development were observed, nor any teratogenic effects during development, although pulmonary inflammation was observed in parental females of rats a NOAEC of $1.0 \mathrm{ppm}$.

More recently, some Chinese scholars (Tang et al., 2020) identified adverse effects of certain pesticides during pregnancy on the placenta and the development of the fetus, investigating the mechanisms of action of the following estrogenic endocrine disruptors: organochlorine pesticides, bisphenol A, phthalates and diethylstilbestrol.

(Sharma et al., 2020) have focused attention on insecticides as they are asso- 
ciated with metabolic disorders, psychological and neurological diseases and hormonal imbalances also for humans. Oxidative stresses and endocrine alterations of insecticides alter the correct functioning of ovarian activities, of the relative cycle, of the ovulation process and follicular maturation, increasing the risk of spontaneous abruptions and malformations of the fetuses.

\subsection{Disorders of Sexual Development and Behavior}

(Hu et al. 2020; Conley et al., 2018), using a mixture of different types of pesticides, drugs and phthalates (procymidone, p,p'-DDE, prochloraz, vinclozolin, finasteride, benzyl butyl, dixyl, flutamide and others), at different dilution doses, on male rats after birth, found a conspicuous variety of adverse effects, both during the neonatal phase and during the pubertal one, concerning consistent reductions in reproductive tissues and malformations of the genital organs even at very low doses of administration.

(Madhubabu \& Yenugu, 2017) evaluated the reproductive toxicity of adult male rats of allethrin at an administration of $25-150 \mathrm{mg} / \mathrm{kg}$ bw for 60 days, noting a significant reduction in steroidogenesis (StAR, 3'-HSD, 17'-HSD), testosterone and sperm count. From numerous studies, it appears that propiconazole (PROP) interferes with the endocrine system, altering the CYP51 enzyme. For example, (Vieira et al., 2017) identified a possible toxicity of PROP by administering this fungicide to two generations of male rats by investigating the most common morphological parameters of possible mutations, such as: anogenital distance and plasma testosterone levels, sperm count and morphology, body weight, etc.

(Hass et al., 2017) experimentally found that, by administering a mixture of six pesticides (quinoclamine, ziram, tiram, primacarb, $\mathrm{MCPB}$ and cyromazine) to Wistar rats, there was a significant decrease in birth weight even at doses below the NOAEL.

(Andrade et al., 2006) investigated the reproductive effects of di-(2-ethylhexyl) phthalate (DEHP) exposure in utero and during the lactation phase for the offspring of male rats. The authors recorded a daily decrease in semen of $19 \%$ $25 \%$ compared to the control guinea pig population, although no obvious abnormalities in sexual behavior were observed at any dose of administration.

\section{Conclusions}

Pesticide molecules have now permanently entered our environment, contaminate water, soil, and food are found in the umbilical cord and in breast milk itself. They act at infinitesimal doses and are now present in real cocktails of active ingredients and interfere with important and very delicate functions such as hormonal, reproductive, and metabolic functions.

Pesticides, in addition to having strong repercussions on biodiversity and short-term toxic effects on those organisms that are affected by direct exposure, could also have long-term effects, such as the transformation of food chain and 
disappearance of particular habitats. There is no doubt that the relationship between human health and pesticides has been the subject of numerous studies, especially with regard to the onset of tumors.

EPA and the European Commission regulate the sector even if they do not always follow the alarms coming from environmental organizations, consumers, and farmers themselves. However, the interventions and initiatives undertaken do not seem sufficient, on the contrary, some go in the opposite direction. As regards the European Commission, for example, standardizing all countries and setting the maximum residue limit for fruit and vegetables (the so-called internal "harmonization"), the measures come into force two years after their publication in the Official Journal of the EU and the trade license of pesticides on the Community market is valid for ten years.

How it was highlighted, it is very urgent and necessary to intensify studies and research on the possible adverse effects-especially those of long-term, low-dose and on non-target living species, animals and plants of pesticides on both humans and animals and environment. On the other hand, international regulatory policy should also constantly adapt to the evolution of scientific knowledge in order to protect human health and safeguard the environment.

Faced with these considerations, it appears increasingly urgent to take, in the short term, as "Primary Prevention", a drastic reduction in exposure to all those chemical and physical agents already widely known for their toxicity and carcinogenicity with the consequent necessity to adopt stronger regulations and laws and stimulating more controls and scientific research.

\section{Conflicts of Interest}

The authors declare no conflicts of interest regarding the publication of this paper.

\section{References}

Ahmad, L., Khan, A., \& Khan, M. Z. (2012). Pyrethroid-Induced Reproductive Toxico-Pathology in Non-Target Species. Pakistan Veterinary Journal, 32, 1-9. https://core.ac.uk/download/pdf/26824825.pdf

Anastassiadou, M., Arena, M., Auteri, D., Brancato, A., Bura, L., Carrasco Cabrera, L. et al. (2020). Peer Review of the Pesticide Risk Assessment of the Active Substance Chloropicrin. EFSA Journal, 18, Article No. e06028. https://doi.org/10.2903/j.efsa.2020.6028

Andrade, A., Grande, S. W., Talsness, C. E., Gericke, C., Grote, K., Golombiewski, A., Sterner-Kock, A., \& Chahoud, I. (2006). A Dose Response Study Following in Utero and Lactational Exposure to Di-(2-ethylhexyl) Phthalate (DEHP): Reproductive Effects on Adult Male Offspring Rats. Toxicology, 228, 85-97. https://doi.org/10.1016/j.tox.2006.08.020

Arce, A. N., David, T. I., Randall, E. L., Rodrigues, A. R., Colgan, T. J., Wurm, Y., \& Gill, R. J. (2017). Impact of Controlled Neonicotinoid Exposure on Bumblebees in a Realistic Field Setting. Journal of Applied Ecology, 54, 1199-1208.

https://doi.org/10.1111/1365-2664.12792 
Auso, E., La-vado-Autric, R., Cuevas, E., del Rey, F. E., Morreale de Escobar, G., \& Berbel, P. (2004). A Moderate and Transient Deficiency of Maternal Thyroid function at the Beginning of Fetal Neocorticogenesis Alters Neuronal Migration. Endocrinology, 145, 4037-4047. https://doi.org/10.1210/en.2004-0274

Ayres, L. P. (1919). The War with Germany: A Statistical Summary (2nd ed., p. 80). US Government Printing Office. https://digital.library.unt.edu/ark:/67531/metadc276266

Banerjee, P., \& Bhattacharya, J. (2020). Impact of Oxidative Stress on Infertility, with Emphasis on Infertility Management Strategies. Global Journal of Fertility and Research, 4, 10-18. https://www.peertechz.com/articles/GJFR-4-112.php https://doi.org/10.17352/gjfr.000012

Bates, M. N., Hamilton, J. W., LaKind, J. S., Langenberg, P., O’Malley, M., \& Snodgrass, W. (2005). Workgroup Report: Biomonitoring Study Design, Interpretation, and Communication-Lessons Learned and Path Forward. Environmental Health Perspectives, 113, 1615-1621. https://doi.org/10.1289/ehp.8197

Beketov, M. A., Kefford, B. J., Schäfer, R. B., \& Liess, M. (2013). Pesticides Reduce Regional Biodiversity of Stream Invertebrates. Proceedings of the National Academy of Sciences of the United States of America, 110, 11039-11043.

https://doi.org/10.1073/pnas.1305618110

Berny, P. (2007). Pesticides and the Intoxication of Wild Animals. The Journal of Veterinary Pharmacology and Therapeutics, 30, 93-100. https://doi.org/10.1111/j.1365-2885.2007.00836.x

Bianco, P. M. (2018). Note sull'inquinamento da pesticidi in Italia. ISDE-Associazione Medici per l'Ambiente.

https://www.isde.it/wp-content/uploads/2018/01/2017.12.-Contaminazione-pesticidi-It alia-finale.pdf

Bjørling-Poulsen, M., Andersen, H. R., \& Grandjean, P. (2008). Potential Developmental Neurotoxicity of Pesticides Used in Europe. Environmental Health, 7, Article No. 50. https://doi.org/10.1186/1476-069X-7-50

Blus, L. J., \& Henny, C. J. (1997). Field Studies on Pesticides and Birds: Unexpected and Unique Relations. Ecological Applications, 7, 1125-1132. https://doi.org/10.1890/1051-0761(1997)007[1125:FSOPAB]2.0.CO;2

Bolognesi, C., \& Merlo, F. D. (2011). Pesticides: Human Health Effects. In J. O. Nriagu, (Ed.), Encyclopedia of Environmental Health (pp. 438-453). Elsevier.

https://doi.org/10.1016/B978-0-444-52272-6.00592-4

Bretveld, R. W., Thomas, C. M. G., Scheepers, P. T. J., Zielhuis, G. A., \& Roeleveld, N. (2006). Pesticide Exposure: The Hormonal Function of the Female Reproductive System Disrupted? Reproduction Biology Endocrinology, 4, Article No. 30. https://doi.org/10.1186/1477-7827-4-30

Bretveld, R., Brouwers, M., Ebisch, I., \& Roeleveld, N. (2007). Influence of Pesticides on Male Fertility. Scandinavian Journal of Work, Environment \& Health, 33, 13-28. https://doi.org/10.5271/sjweh.1060

Carson, R. (1962). Silent Spring. Houghton Mifflin Harcourt. https://library.uniteddiversity.coop/More_Books_and_Reports/Silent_Spring-Rachel_C arson-1962.pdf

Chapin, F. S., Zavaleta, E. S., Eviner, V. T., \& Naylor, R. L. (2020). Consequences of Changing Biodiversity. Nature, 405, 234-242. https://doi.org/10.1038/35012241

Conley, J. M., Lambright, C. S., Evans, N., Cardon, M. (2018). Mixed “Antiandrogenic” Chemicals at Low Individual Doses Produce Reproductive Tract Malformations in the Male Rat. Toxicological Sciences, 164, 166-178. https://doi.org/10.1093/toxsci/kfy069 
Das, S. K. (2013). Mode of Action of Pesticides and the Novel Trends-A Critical Review. International Research Journal of Agricultural Science and Soil Science, 3, 393-401.

De Neri, A. (2020). Neppure l'Evian è stata risparmiata dai pesticidi (Not Even Evian Is Spared from Pesticides).

https://m.tio.ch/svizzera/attualita/1448903/acqua-evian-pesticidi-ricercatori-residui

Dinis-Oliveira, R. J., Remião, F., Carmo, H., Duarte, J. A., Navarro, A., Sánchez Bastos, M. L., \& Carvalho F. (2006). Paraquat Exposure as an Etiological Factor of Parkinson's Disease. NeuroToxicology, 27, 1110-1122. https://doi.org/10.1016/j.neuro.2006.05.012

Donley, N. (2020). Toxic Hangover: How the EPA Is Approving Nw Product with Dangerous Pesticides It Committed to Phasing Out. Center for Biological Diversity.

Dubus, I. G., Hollis, J. M., \& Brown, C. D. (2000). Pesticide in Rainfall in Europe. Environmental Pollution, 110, 331-344. https://doi.org/10.1016/S0269-7491(99)00295-X

Eng, M. L., Stutchbury, B. J. M., \& Morrissey, C. A. (2017). Imidacloprid and Chlorpyrifos Insecticides Impair Migratory Ability in a Seed-Eating Songbird. Scientific Reports, 7, Article No. 15176. https://doi.org/10.1038/s41598-017-15446-X

Eng, M. L., Stutchbury, B. J. M., \& Morrissey, C. A. (2019). A Neonicotinoid Insecticide Reduces Fueling and Delays Migration in Songbirds. Science, 365, 1177-1180. https://doi.org/10.1126/science.aaw9419

Eurostat (2008). A Common Methodology for the Collection of Pesticide Usage Statistics within Agriculture and Horticulture. Office for Official Publications of the European Communities.

Eurostat (2020). Sales of Pesticides in the EU. https://ec.europa.eu/eurostat/web/products-eurostat-news/-/ddn-20200603-1

Ewald, J. A., Wheatley, C. J., Aebischer, N. J., Moreby, S. J., Duffield, S. J., Crick, H. Q. P., \& Morecroft, M. B. (2015). Influences of Extreme Weather, Climate and Pesticide Use on Invertebrates in Cereal Fields over 42 Years. Global Change Biology, 21, 3931-3950. https://doi.org/10.1111/gcb.13026

FAO (Food and Agriculture Organization of the United Nations) (2021). FAOSTAT: Statistics on Pesticides Use in Agriculture, 1990-2018. Pesticides Use Domain. http://www.fao.org/economic/ess/environment/data/pesticides-use/en

Frazier, L. M. (2007). Reproductive Disorders Associated with Pesticide Exposure. Journal of Agromedicine, 12, 27-37. https://doi.org/10.1300/J096v12n01_04

Frederickson, D., Wohlman, M., Stoddard, D., Regimbal, G., Scholer, J., Zachmann, J., Ortiz-Ribbing, L., \& Mann, R. (2016). Review of Neonicotinoid Use, Registration, and Insect Pollinator Impacts in Minnesota. Minnesota Department of Agriculture. https://www.mda.state.mn.us/sites/default/files/inline-files/neonicreviewrpt2016.pdf

Gardella, J. R., \& Hill, J. A. (2000). Environmental Toxins Associated with Recurrent Pregnancy Loss. Seminars in Reproductive Medicine, 18, 407-424.

https://doi.org/10.1055/s-2000-13731

Geiger, F., Bengtsson, J., Berendse, F., Weisser, W. W., Emmerson, M., Morales, M. B., Ceryngier, P. et al. (2010). Persistent Negative Effects of Pesticides on Biodiversity and Biological Control Potential on European Farmland. Basic and Applied Ecology, 11, 97-105. https://doi.org/10.1016/j.baae.2009.12.001

Geissen, V., Silva, V., Lwanga, E. H., Beriot, N., Oostindie, K., Bin, Z., Pyne, E., Busink, S., Zomer, P., Mol, H., \& Ritsema, C. J. (2021). Cocktails of Pesticide Residues in Conventional and Organic Farming Systems in Europe-Legacy of the Past and Turning Point for the Future. Environmental Pollution, 278, Article ID: 116827.

https://doi.org/10.1016/j.envpol.2021.116827 
Ghuman, S. P. S., Ratnakaran, U., Bedi, J. S., \& Gill, J. P. S. (2013). Impact of Pesticide Residues on Fertility of Dairy Animals: A Review. Indian Journal of Animal Sciences, 83, 1243-1255.

https://www.researchgate.net/publication/274081193_Impact_of_pesticide_residues_o n_fertility_of_dairy_animals_A_review

Gómez-Baggethun, E., \& Martín-López, B. (2010). The Socio-Economic Costs of Biodiversity Loss. Lychnos, 3, 68-74.

http://www.fgcsic.es/lychnos/upload/publicacion.7.ficPDF_ingles.Lychnos3_ENG.pdf

Grandjean, P., \& Landrigan, P. J. (2006). Developmental Neurotoxicity of Industrial Chemicals. Lancet, 368, 2167-2178. https://doi.org/10.1016/S0140-6736(06)69665-7

Gray, L. E. (1992). Chemical-Induced Alterations of Sexual Differentiation: A Review of Effects in Humans and Rodents. In T. Colborn, \& C. Clement (Eds.), Chemically-Induced Alterations in Sexual and Functional Development. The Wildlife/Human Connection (pp. 203-230). Princeton Scientific Publishing Co., Inc.

Gray, L. E., \& Ostby, J. (1998). Effects of Pesticides and Toxic Substances on Behavioral and Morphological Reproductive Development: Endocrine versus Nonendocrine Mechanisms. Toxicology \& Industrial Health, 14, 159-184. https://doi.org/10.1177\%2F074823379801400111

Gro (2018, June 11). A Look at Fertilizer and Pesticide Use in the USA. https://gro-intelligence.com/insights/articles/a-look-at-fertilizer-and-pesticide-use-in-the-us

Hallmann, C. A., Sorg, M., Jongejans, E., Siepel, H., Hofland, N. et al. (2017). More than 75 Percent Decline over 27 Years in Total Flying Insect Biomass in Protected Areas. PLoS ONE, 12, e0185809. https://doi.org/10.1371/journal.pone.0185809

Hance, J. (2019, June 6). The Great Insect Dying: Vanishing Act in Europe and North America. Mongabay.

https://news.mongabay.com/2019/06/the-great-insect-dying-vanishing-act-in-europe-a nd-north-america

Hass, U., Christiansen, S., Axelstad, M., Scholze, M., \& Boberg, J. (2017). Combined Exposure to Low Doses of Pesticides Causes Decreased Birth Weights in Rats. Reproductive Toxicology, 72, 97-105. https://doi.org/10.1016/j.reprotox.2017.05.004

Hernández, A. F., Gil, F., \& Lacasaña, M. (2017). Toxicological Interactions of Pesticide Mixtures: An Update. Archives of Toxicology, 91, 3211-3223.

https://doi.org/10.1007/s00204-017-2043-5

Hu, Y., Zhang, Y., Vinturache, A., Wang, Y., Shi, R., Chen, L., Qin, K., Tian, Y., \& Gao, Y. (2020). Effects of Environmental Pyrethroids Exposure on Semen Quality in Reproductive Age Men in Shanghai, China. Chemosphere, 245, Article ID: 125580. https://doi.org/10.1016/j.chemosphere.2019.125580

Hussain, S., Siddique, T., Saleem, M., Arshad, M., \& Khalid, A. (2009). Impact of Pesticides on Soil Microbial Diversity, Enzymes, and Biochemical Reactions. Advances in Agronomy, 102, 159-200. https://doi.org/10.1016/S0065-2113(09)01005-0

ISPRA (Italian Institute for Environmental Protection and Research) (2018). Rapporto nazionale pesticidi nelle acque. Dati 2017-2018. Edizione 2018.

https://www.isprambiente.gov.it/it/pubblicazioni/rapporti/rapporto-nazionale-pesticidi -nelle-acque-dati-2017-2018

Ito, H. C., Shiraishi, H., Nakagawa, M., \& Takamura, N. (2020). Combined Impact of Pesticides and Other Environmental Stressors on Animal Diversity in Irrigation Ponds. PLoS ONE, 15, e0229052. https://doi.org/10.1371/journal.pone.0229052

Kavlock, R. J., Daston, G. P., Derosa, C., Fenner-Crisp, P., Gray, L. E., Kaattari, S. et al. (1996). Research Needs for the Risk Assessment of Health and Environmental Effects 
of Endocrine Disruptors: A Report of the U.S. EPA-Sponsored Workshop. Environmental Health Perspectives, 104, 715-740. https://doi.org/10.1289/ehp.96104s4715

Koli, P., Bhardwaj, N. R., \& Mahawer, S. K. (2019). Agrochemicals: Harmful and Beneficial Effects of Climate Changing Scenarios. In K. K. Choudhary, A. Kumar, \& A. K. Singh (Eds.), Climate Change and Agricultural Ecosystems: Current Challenges and Adaptation (pp. 65-94). Elsevier. https://doi.org/10.1016/B978-0-12-816483-9.00004-9

Leoci, R., \& Ruberti, M. (2020a). Glyphosate in Agriculture: Environmental Persistence and Effects on Animals: A Review. Journal of Agriculture and Environment for International Development, 114, 99-122.

Leoci, R., \& Ruberti, M. (2020b). Isoproturon: A Controversial Herbicide Hard to Confine in a Global Market. Journal of Sustainable Development, 13, 43-54. https://doi.org/10.5539/jsd.v13n6p43

Li, A. J., Chen, Z., Lin, T. C., Louis, G. M. B., \& Kannan, K. (2020). Association of Urinary Metabolites of Organo-Phosphate and Pyrethroid Insecticides, and Phenoxy Herbicides with Endometriosis. Environment International, 136, Article ID: 105456. https://doi.org/10.1016/j.envint.2019.105456

Lindbohm, M. L., \& Sallmén, M. (2017). Reproductive Effects Caused by Chemical and Biological Agents. https://oshwiki.eu/wiki/Reproductive_effects_caused_by_chemical_and_biological_agents

Long, E. Y., \& Krupke, C. H. (2016). Non-Cultivated Plants Present a Season-Long Route of Pesticide Exposure for Honey Bees. Nature Communications, 7, Article No. 11629. https://doi.org/10.1038/ncomms11629

Lushchak, V. I., Matviishyn, T. M., Husak, V. V., Storey, J. M., \& Storey, K. B. (2018). Pesticide Toxicity: A Mechanistic Approach. EXCLI Journal, 17, 1101-1136. https://doi.org/10.17179/excli2018-1710

MacArthur, E. R., \& Murray, B. C. (1993). Pesticide Industry: A Profile, Draft Report. US-EPA Contract Number 68-D1-0143, U.S. Environmental Protection Agency.

MacKinnon, D. S., \& Freedman, B. (1993). Effects of Silvicultural Use of the Herbicide Glyphosate on Breeding Birds of Regenerating Clearcuts in Nova Scotia, Canada. Journal of Applied Ecology, 30, 395-406. https://doi.org/10.2307/2404181

Madhubabu, G., \& Yenugu, S. (2017). Allethrin Toxicity Causes Reproductive Dysfunction in Male Rats. Environmental Toxicology, 32, 1701-1710. https://doi.org/10.1002/tox.22394

Maggi, F., Tang, F. H. M., La Cecilia, D., \& McBratney, A. (2019). PEST-CHEMGRIDS, Global Gridded Maps of the Top 20 Crop-Specifc Pesticide Application Rates from 2015 to 2025. Scientific Data, 6, Article No. 170. https://doi.org/10.1038/s41597-019-0169-4

Mahmood, I., Imadi, S. R., Shazadi, K., Gul, A., \& Hakeem, K. R. (2016). Effects of Pesticides on Environment. In K. Hakeem, M. Akhtar, \& S. Abdullah (Eds.), Plant, Soil and Microbes (pp. 253-269). Springer. https://doi.org/10.1007/978-3-319-27455-3_13

Maksymiv, I. (2015). Pesticides: Benefits and Hazards. Journal of Vasyl Stefanyk Precarpathian National University, 2, 70-76. https://doi.org/10.15330/jpnu.2.1.70-76

Meftaul, I. M., Venkateswarlu, K., Dharmarajan, R., Annamalai, P., \& Megharaj, M. (2020). Pesticides in the Urban Environment: A Potential Threat That Knocks at the Door. Science of the Total Environment, 711, Article ID: 134612. https://doi.org/10.1016/j.scitotenv.2019.134612

Mesnage, R., Defarge, N., Spiroux de Vendômois, J., \& Séralini, G. E. (2014). Major Pesticides Are More Toxic to Human Cells than Their Declared Active Principles. BioMed 
Research International, 2014, Article ID: 179691.

https://doi.org/10.1155/2014/179691

Milo, D. (2020). Gli svizzeri hanno un cocktail di pesticidi nelle urine. TIO 20.

https://www.tio.ch/svizzera/cronaca/1438747/pesticidi-residui-sosta_nze-urine-cocktail

Mnif, W., Ibn Hadj Hassine, A., Bouaziz, A., Bartegi, A., Thomas, O., \& Roig, B. (2011). Effect of Endocrine Disruptor Pesticides: A Review. International Journal of Environmental Research and Public Health, 8, 2265-2303. https://doi.org/10.3390/ijerph8062265

Mridula, C., Chetna, S., \& Mamta, C. (2013). Effects of Pesticides on Human Beings and Farm Animals: A Case Study. Research Journal of Chemical and Environmental Sciences, 1, 14-19. http://www.aelsindia.com/Vollaugust_2013/4.pdf

Nare, R. W. A., Windinpsidi Savadogo, P., Traore, M., Gountan, A., Bismarck Nacro, H., \& Papaoba Sedogo, M. (2017). Soil Macrofauna Behaviour in the Presence of Pesticides and Organic Amendments. Journal of Geoscience and Environment Protection, 5, 202-212. https://doi.org/10.4236/gep.2017.53014

Newton, I. (2004). The Recent Declines of Farmland Bird Populations in Britain: An Appraisal of Causal Factors and Conservation Actions. Ibis, 146, 579-600. https://doi.org/10.1111/j.1474-919X.2004.00375.x

NRC (National Research Council) (1993). Pesticides in the Diets of Infants and Children. National Academy Press.

O'Malley, M. (2010). The Regulatory Evaluation of the Skin Effects of Pesticides. In R. Krieger (Ed.), Hayes' Handbook of Pesticide Toxicology (3rd ed., pp. 701-787). Academic Press. https://doi.org/10.1016/B978-0-12-374367-1.00028-8

OECD (Organisation for Economic Co-Operation and Development) (2019). Biodiversity: Finance and the Economic and Business Case for Action. Report Prepared for the G7 Environment Ministers' Meeting, Metz, 5-6 May 2019, 29-30.

https://www.oecd.org/env/resources/biodiversity/biodiversity-finance-and-the-econom ic-and-business-case-for-action.htm

Oliveira, J. M., Destrob, A. L. F., Freitasb, M. B., \& Oliveira, L. L. (2020). How Do Pesticides Affect Bats? A Brief Review of Recent Publications. Brazilian Journal of Biology, 81, 499-507. https://doi.org/10.1590/1519-6984.225330

Oriel, M., Edmiston, S., Beauvais, S., Barry, T., \& O’Malley, M. (2009). Illnesses Associated with Chloropicrin Use in California Agriculture, 1992-2003. In D. M. Whitacre (Ed.), Reviews of Environmental Contamination and Toxicology (Vol. 200, pp. 1-31). Springer Science Business Media.

https://www.researchgate.net/publication/226664927_Illnesses_Associated_with_Chlor opicrin_use_in_California_Agriculture_1992_-_2003 https://doi.org/10.1007/978-1-4419-0028-9_1

Phelps, J. D., Strang, C. G., \& Sherry, D. F. (2020). Imidacloprid Impairs Performance on a Model Flower Handling Task in Bumblebees (Bombus Impatiens). Ecotoxicology, 29, 359-374. https://doi.org/10.1007/s10646-020-02182-8 https://ir.lib.uwo.ca/cgi/viewcontent.cgi?article=7567\&context=etd

Prentiss, A. (1937). Chemicals in War: A Treatise on Chemical Warfare (pp. 140, 161, 525, 625). McGraw-Hill.

Raman, P. (2014). Chloropicrin. In P. Wexler (Ed.), Encyclopedia of Toxicology (3rd ed., pp. 903-906). Academic Press. https://doi.org/10.1016/B978-0-12-386454-3.00282-7 https://www.sciencedirect.com/referencework/9780123864550/encyclopedia-of-toxicol ogy

Rattan, S., Zhou, C., Chiang, C., Mahalingam, S., Brehm, E., \& Flaws, J. A. (2017). Expo- 
sure to Endocrine Disruptors during Adulthood: Consequences for Female Fertility. Journal of Endocrinology, 233, R109-R129. https://doi.org/10.1530/JOE-17-0023

Reynoso, E. C., Torres, E., Bettazzi, F., \& Palchetti, I. (2019). Trends and Perspectives in Immunosensors for Determination of Currently-Used Pesticides: The Case of Glyphosate, Organophosphates, and Neonicotinoids. Biosensors, 9, Article No. 20. https://doi.org/10.3390/bios9010020

Ritter, L., Solomon, K., Sibley, P., Hall, K., Keen, P., Mattu, G. et al. (2002). Sources, Pathways, and Relative Risks of Contaminants in Surface Water and Groundwater: A Perspective Prepared for the Walkerton Inquiry. Journal of Toxicology and Environmental Health, 65, 1-142. https://doi.org/10.1080/152873902753338572

Sciuto, A. M., \& Kodavanti, U.P. (2015). The Respiratory Toxicity of Chemical Warfare Agents. In R. C. Gupta (Ed.), Handbook of Toxicology of Chemical Warfare Agents (2nd ed., pp. 489-518). Academic Press. https://doi.org/10.1016/B978-0-12-800159-2.00036-1

Sharara, F. I., Seifer, D. B., \& Flaws, J. A. (1998). Environmental Toxicants and Female Reproduction. Fertility and Sterility (Modern Trends), 70, 613-622. https://doi.org/10.1016/S0015-0282(98)00253-2

Sharma, R. K., Singh, P., Setia, A., \& Sharma, A. K. (2020). Insecticides and Ovarian Functions. Environmental and Molecular Mutagenesis, 61, 369-392.

https://doi.org/10.1002/em.22355

Sifakis, S., Androutsopoulos, V. P., Tsatsakis, A. M., \& Spandidos, D. A. (2017). Human Exposure to Endocrine Disrupting Chemicals: Effects on the Male and Female Reproductive Systems. Environmental Toxicology Pharmacology, 51, 56-70. https://doi.org/10.1016/j.etap.2017.02.024

Silva, V., Mol, H. G. J., Zomer, P., Tienstra, M., Ritsema, C. J., \& Geissen, V. (2019). Pesticide Residues in European Agricultural Soils-A Hidden Reality Unfolded. Science of the Total Environment, 653, 1532-1545. https://doi.org/10.1016/j.scitotenv.2018.10.441

Steer, P. J. (1993). Chemically Induced Birth Defects (2nd ed.). Revised and Expanded by James L. Schardein, Marcel Dekker, Inc.

Stehle, S., \& Schulz, R. (2015). Pesticide Authorization in the EU: Environment Unprotected? Environmental Science and Pollution Research, 22, 19632-19647. https://doi.org/10.1007/s11356-015-5148-5

Szalárdy, L. (2006). Neuropathological Characterization of FL-PGC-1a-Deficient Mice-Implications for Mitochon-Drial Encephalopathy. PhD Thesis, Department of Neurology, Faculty of Medicine, Albert Szent-Györgyi Clinical Center, University of Szeged.

http://doktori.bibl.u-szeged.hu/id/eprint/3120/1/Szal\%C3\%A1rdy\%20Levente\%20Diss zert\%C3\%A1ci\%C3\%B3.pdf

Tang, Z. R., Xu, X. L., Deng, S. L., Lian, Z. X., \& Yu, K. (2020). Oestrogenic Endocrine Disruptors in the Placenta and the Fetus. International Journal of Molecular Sciences, 21, Article No. 1519. https://doi.org/10.3390/ijms21041519

Tiryaki, O., \& Temur, C. (2010). The Fate of Pesticide in the Environment. Journal of Biological and Environmental Sciences, 4, 29-38.

https://www.researchgate.net/publication/303720878_The_fate_of_pesticide_in_the_en vironment

Tomizawa, M., \& Casida, J. E. (2003). Selective Toxicity of Neonicotinoids Attributable to Specificity of Insect and Mammalian Nicotinic Receptors. Annual Review of Entomology, 48, 339-364. https://doi.org/10.1146/annurev.ento.48.091801.112731 
Trasande, L., Zoeller, R. T., Hass, U., Kortenkamp, A., Grandjean, P., Myers, J. P., Di Gangi, J. et al. (2015). Estimating Burden and Disease Costs of Exposure to Endocrine-Disrupting Chemicals in the European Union. The Journal of Clinical Endocrinology and Metabolism, 100, 1245-1255. https://doi.org/10.1210/jc.2014-4324

Upadhyay, S. K. (2019). Effect of Pesticides Exposure on Human Health and Reproductive Life. Journal of Complementary Medicine \& Alternative Healthcare, 10, Article ID: 555782.

Van Oers, L., Tamis, W., De Koning, A., \& De Snoo, G. (2005). Review of Incidents with Wildlife Related to Paraquat. CML Report No. 165. Institute of Environmental Sciences.

https://www.leidenuniv.nl/interfac/cml/bieb_internet/publications/cml_rapporten/cml \%20report\%20165_review_incidents_wildlife_related_to_paraquat.pdf

Vidal, J. L. M., \& Frenich, A. G. (2006). Pesticide Protocols. Humana Press Inc.

Vieira, M. L., Costa, N. O., \& Pereira, M. R. F. (2017). Chronic Exposure to the Fungicide Propiconazole: Behavioral and Reproductive Evaluation of F1 and F2 Generations of Male Rats. Toxicology, 389, 85-93. https://doi.org/10.1016/j.tox.2017.07.012

Vogel, G. (2017). Where Have All the Insects Gone? Science, 356, 576-579. https://doi.org/10.1126/science.356.6338.576

Wolf Jr., C., Lambright, C., Mann, P., Price, M., Cooper, R. L., Ostby, J., \& Gray, L. E. (1999). Administration of Potentially Antiandrogenic Pesticides (procymidone, Linuron, Iprodione, Chlozolinate, p,p'-DDE, and Ketoconazole) and Toxic Substances (Dibutyl- and Diethylhexyl Phthalate, PCB 169, and Ethane Dimethane Sulphonate) during Sexual Differentiation Produces Diverse Profiles of Reproductive Malformations in the Male Rat. Toxicology \& Industrial Health, 15, 94-118.

https://doi.org/10.1177\%2F074823379901500109

Yoshida, M. A, Ikeda, T., Iwasaki, M., Ikeda, M., \& Harada, T. (1987). Subchronic Inhalation Toxicity of Chloropicrin Vapor in Rats. Journal of Pesticide Science, 12, 673-681. https://doi.org/10.1584/jpestics.12.673

Yu-Han, C., Paige, L. W., Gillman, M. W., Gaskins, A. J., Mínguez-Alarcón, L., Souter, I., Toth, T. L., Ford, J. B., Hauser, R., \& Chavarro, J. E. (2018). Association between Pesticide Residue Intake from Consumption of Fruits and Vegetables and Pregnancy Outcomes among Women Undergoing Infertility Treatment with Assisted Reproductive Technology. JAMA Internal Medicine, 178, 17-26.

https://doi.org/10.1001/jamainternmed.2017.5038 